\title{
A Jurisdição Constitucional na Fase Atual de Desenvolvimento do Estado Constitucional'
}

Peter Häberle ${ }^{2}$

\section{Introdução}

O tema escolhido é um tema solene para um dia festivo e, ao mesmo tempo, um tema prático de trabalho e do dia-a-dia. Para um alemão é a maior honra poder tratá-lo na "consulta", na presença dos representantes supremos do órgão constitucional da Itália, a Itália européia.

O genius loci do tipo singular de Roma, representativa também do começo da cultura jurídica européia, poderia ser inspirador para todos nós. Na "Sala de Imagens dos Tempos", nós, os juristas, podemos atravessá-la aqui sempre de novo. Em Roma vemos monumentos e documentos por onde quer que seja, com os quais vinculamos a eterna luta pela justiça: desde as XII Tábuas até os Tratados de Roma ou os despachos em que foram criados. Em relação às pessoas, têm muito para escolher caso se rememorem as estátuas de sua Corte de Cassação, desde Cícero até Gayo. Não foram, nem são, só as instituiçōes, como hoje os órgãos constitucionais, os que trabalham ao serviço do Direito, mas também o fazem pessuas concretas, como os juizes constitucionais.

\footnotetext{
1 Texto da conferência realizada pelo autor nas Jornadas de Estudo do Tribunal Constitucional Italiano, em Roma, no dia 30 de maio de 2003, na presença do Presidente da República Italiano, Sr. Ciampi. O texto agora traduzido foi publicado em alemão, na Europäische Grundrechte Zeitschrift, Editorial N. P. Engel, Kehl am Rhein/Estrasburgo/Arlington, Fascículos 5-8, de 26 de abril de 2004, p. 117-125. Tradução do alemão para o espanhol: Joaquín Brage Camazano. Doutor Europeu em Direito (UCM). Departamento de Direito Constitucional. Universidade Complutense de Madri. Tradução do espanhol para o português: Tânia Abrão Rangel. Mestre em Direito Empresarial pela Universidade de Franca (SP) e em Derecho de los Negocios pela Universidad Francisco de Vitória (Madri - Espanha).

2 Professor Titular de Direito Público e de Filosofia do Direito da Universidade da Augsburg-RFA.
} 
Tratar nosso exigente tema de hoje é algo que só pode ser feito "sobre os ombros de gigantes". Na Alemanha são "os gigantes de Weimar", na Itália são, sobretudo, grandes juristas da época do pós-guerra, que, como membros da Assembléia Constituinte e/ou como juízes constitucionais de sua Corte ${ }^{3}$ em Roma, colocaram em andamento, ou mantiveram em funcionamento, a grande Constituição de 1947. Deve-se pensar em C. Gortari, A. Sandulli e L. Paladi, ${ }^{4}$ para mencionar somente os falecidos.

A partir de uma perspectiva européia, a Corte trabalha há muito tempo um lugar destacado no círculo dos tribunais constitucionais nacionais e dos outros tribunais constitucionais europeus. Isso se manifesta em muitas formas e foros: assim, nos seminários regulares dentro da Corte sobre temas como a proporcionalidade, o Direito europeu, a imunidade parlamentar, a interpretação constitucional, a cujo efeito também convida a acadêmicos externos; se mostra na participação dos encontros institucionalizados de juízes constitucionais de toda a Europa (em 1999, por exemplo, em Varsóvia, em 2002, em Bruxelas) e não em último termo no convite e integração de jovens científicos de países próximos e distantes, que "trabalham" a Corte iuscomparativamente.

Sob a direção de P. Ridola há atualmente lugares entre vocês, não só os espanhóis e os franceses, mas também os colombianos. Mas são, sobretudo, algumas decisões particulares da Corte as que têm causado grande impressão ao largo de toda a Europa em muitos constitucionalistas e levam a um diálogo intensivo. ${ }^{5}$ Deve-se mencionar, por exemplo, a jurisprudência sobre a liberdade religiosa $\mathrm{e}$ suas conseqüências para o Direito eleitoral, sobre a liberdade de crença e o princípio constitucional de laicidade, a jurisprudência sobre a proteção de minorias (discriminação da minoria lingüística ladina no Tirol do Sul, assim como sobre a pretensão da minoria lingüística eslovena), sobre o fortalecimento das regiōes e sobre a Constituição no que se refere aos meios de comunicação social (para configurar de maneira pluralista), sobre a práxis inconstitucional da reiteração de re-

\footnotetext{
3 “Corte." Assim, no original alemão. De agora em diante, não se indicará nada a respeito desta palavra quando aparecer tal qual o texto alemão (Nota do Tradutor Alemão - Espanhol).

4 Sobre L. Paladin: F. Lanchester, Livio Paladin, Jahrbuch des öffentlichen Rechts, número 49 (2001), p. 349 ss; sobre C. Mortati: I. Staff, Verfassungstheoretische Probleme in der demokratischen Republik Italien, Der Staat, 1996, p. 271 ss.

5 Exposiçōes regulares sobre o Tribunal Constitucional italiano e sua jurisprudência encontram-se em Jahrbuch des öffentlichen Rechts. Por exemplo: G. Azzariti, Die Stellung des Verfassungsgerichtshofs in der italienischen Staatsordnung, Jahrbuch des öffentlichen Rechts 8 (1959), p. 13 ss, com o Regulamento [interno] geral de funcionamento como apêndice (p. $25 \mathrm{ss)}$ ) W. Leisner, Die klassischen Freiheitsrechte in der italienischen Verfassungsrechtsprechung, Jahrbuch des öffentlichen Rechts 10 (1961), p. 243 ss; F. Pierandrei, Prinzipien der Verfassungsinterpretation in Italien, Jahrbuch des öffentlichen Rechts 12 (1963), p. 201 ss; C. Rossano, Der Gleichheitssatz und seine Bedeutung für die italienische Verfassung, Jahrbuch des öffentlichen Rechts 18 (1969), p. 201 ss. De tempo mais recente: Jurisprudência da Corte, por exemplo por J. Luther, Die Verfassung in Zeiten des 'Übergangs': Italienische Betrachtungen, Jahrbuch des offentlichen Rechts 50 (2002), p. 331 ss (348 ss); M. Hartwig, "Die Rechtsprechung des italienischen Verfassungsgerichts zur Hörfunk - und Fernsehordnung", Zeitschrift für ausländisches offentliches Recht und Völkerrecht 47 (1987), p. 697 ss.
} 
gulamentos legais, sobre o direito fundamental à saúde e o direito de defesa com auxílio de um intérprete. ${ }^{6}$ Devem-se mencionar especialmente as grandes sentenças sobre as relações entre a Corte e a autonomia das Salas. O espaço público europeu da jurisdição constitucional e a Ciência constitucional que se manifesta em Revistas e Anuários, em comentários e artigos, se constitui, a curto e a longo prazo, também a partir de sentenças chaves da Corte em Roma. ${ }^{7}$

No marco deste "afunilamento" como preâmbulo às três partes desta apresentação, isto é, à tríade da comparação jurídica no tempo e no espaço (primeira parte), o marco teórico (segunda parte) e uma seleção de questôes individuais atuais sobre a jurisdição constitucional de hoje (terceira parte), deve-se postular, já neste momento, a tese da autonomia da teoria do Direito constitucional. Como ciência, esta é a "busca eterna da verdade" no sentido de W. von Humboldt; não se esgota por isso no comentário das grandes funções da jurisdição constitucional, mas deve apresentar propostas teóricas "autônomas", "tenazes", "julgar" novos paradigmas, que logo um juiz constitucional pode reelaborar, "orientando a justiça", no sentido de uma integração pragmática de muitos elementos teóricos. A ciência jurídico-constitucional não pode degenerar-se em um mero "(pós)glosador" da jurisdição constitucional, um perigo reconhecido sobretudo na Alemanha. ${ }^{8}$ Este Credo 9 é fé e conhecimento ("Erkenntnis und Bekenntnis") em um, algo que não se pode evitar nas questōes básicas. A Ciência não se legitima a partir da democracia, não emana do povo, está protegida por um direito fundamental de um modo autônomo "por si", por mais que tenha responsabilidade ante a comunidade democrática. A jurisdição constitucional se fundamenta, por fim, através da cadeia democrática de legitimação "do povo aos órgãos estatais" (U. Scheuner).

No meio de tudo isso, deve-se observar o cruzamento das opiniōes interna e externa sobre nosso tema. Eu somente posso dar "opiniōes externas" sobre a jurisdição constitucional, mas rogo, entretanto, por este ganho cultural do Estado constitucional "de dentro", por parafrasear uma sentença de Ortega y Gasset relativa a Goethe. No final, só os próprios juízes constitucionais podem formular

\footnotetext{
6 Decisōes particulares são reproduzidas (em alemāo) em Europäische Grundrechte Zeitschrift, 1997, p. 360 ss; 1998, p. 662 ss; 1999, p. 375 ss; p. 373 ss; 1999, p. 132 ss (revisada por J. Luther); 2000, p. 542 ss (revisada por J. Luther); 2000, p. 237 ss (revisada por J. Luther); 2000, p. 163 ss (revisada por J. Luther); 2002, p. 613 ss (revisada por J. Luther).

7 Exemplares a respeito da rudimentalidade e da arte da resenha jurisprudencial são os informes jurisprudenciais de T. Ritterspach, também com regularidade: por exemplo, Europäische Grundrechte Zeitschrift, 1988, p. 41 ss; p. 70 ss, ibidem; p. 106 ss; ibidem, p. 159 ss; 559 ss; s. auch Europäische Grundrechte Zeitschrift, 1989, p. 40 ss, 202 ss, 227 ss, 331 ss; logo, do mesmo, em: Europäische Grundrechte Zeitschrift, 1990, p. 25 ss, 74 ss, 211 ss, 423 ss; mais adiante, Europäische Grundrechte Zeitschrift, 1991, p. 30 ss, 376 ss; Europäische Grundrechte Zeitschrift, 1992, p. 77 ss, 105 ss, 414 ss. A grande tradição é agora continuada por J. Luther. Do mesmo, veja a tese doutoral: Die italienische Verfassungsgerichtsbarkeit, 1990, e também M. Dietrich, Der italienische Verfassungsgerichtshof, 1993.

8 Sobre isso, recentemente, M. Kloepfer, om Zustand des Verfassungsrechts, Juristen Zeitung, 2003, p. 481 (483 ss).

9 “Credo." Assim se encontra no original alemão (Nota do Tradutor do Alemão para o Espanhol).
} 
e expressar suas "opinióes internas". Isto é detectado, por exemplo, na pergunta de quanto se aventuram os juízes a entrar no processo político (palavra-chave: movimento pendular de "judicial activism" e "judicial restraint"); como moderadamente recorrem à possibilidade, por exemplo, na Espanha e na Alemanha (possibilidade que não está disponível ainda na Itália), do voto particular, quanto trabalham com obiter dicta e com que intensidade qualificam uma única teoria como "correta" na sentença no lugar de integrar harmonicamente elementos teóricos.

Também o estilo da sentença, imperativo ou apodíctico, "dogmático" ou modesto, pode expressar a autoconcepção do juiz constitucional: tanto na Europa como nos Estados Unidos há grandes diferenças, como também em matéria de técnicas de citar. ${ }^{10}$ Ao Tribunal Constitucional Federal alemão, por exemplo, lhe encantam, além do federalismo de que nos orgulhamos, as grandes decisōes que parecem exercícios de habilitação [ao professorado universitário]; França seduz com sua brevidade e concisão cartesianas, com sua elegância e estilo.

Finalmente, pode-se reconhecer na cultura lingüística das decisões jurídicoconstitucionais muita "concepção própria": popular ou em gíria acadêmica. Mas um evento festivo como o de hoje também oferece a possibilidade de trocar "opiniōes internas e externas" sobre a jurisdição constitucional em um e num mesmo foro. Aproveitemos esta oportunidade sem temor.

\section{PRIMEIRA PARTE: FASES HISTÓRICAS DE DESENVOLVIMENTO DA JURISDIÇÃO CONSTITUCIONAL; COMPARAÇÃO JURÍDICA NO TEMPO E NO ESPAÇO}

Só a título de introdução, lembrem-se das etapas de desenvolvimento histórico do hoje exitoso modelo da "jurisdição constitucional", de tal modo que a exploração nas duas dimensões do tempo (a história) e o espaço (a comparação) reúne ambas como dois lados da mesma matéria: a "jurisdição constitucional" (na dimensão institucional, de competência e pessoal).

\section{A fase inicial anterior à Segunda Guerra Mundial}

Junto à "jurisdição constitucional não autônoma" na forma da Supreme Court dos Estados Unidos (Marbury versus Madison tiveram seu ducentésimo aniversário) e junto ao Tribunal do Estado da Constituição do Império de Weimar, dotado somente com modestas competências mas respeitavelmente autônomo (1919), o mérito de ser o pioneiro, o devemos a Áustria. Este país, junto com os relevantes textos clássicos de Hans Kelsen, fez surgir a jurisdição constitucional autônoma. Seu efeito exemplificador irradia consideravelmente a médio e a longo prazos. As primeiras idéias federais tiveram eficácia legitimadora especialmente na Alema-

10 Sobre o diferente estilo sentenciador: P. Häberle, Kommentierte Verfassungsrechtsprechung, 1979, p. 30 ss. 
nha, ${ }^{11}$ o que é uma chave do velho Conselho Federal da Constituição de Bismarck de 1871 (artigo 76).

Certamente, os antecedentes se remontam até a Constituição da Igreja de São Paulo de 1849 ( $\$ 125$ a 128) e é um gosto muito alemão, até hoje utilizado, pretender decidir as controvérsias o mais intensivamente possível ante os tribunais e não tanto político-democraticamente [recentemente, nos assuntos AWACS ou Guerra do Iraque: BVerfGE 90, 286 ou Europäische Grundrechte Zeitschrift 1994, 281; 100, 266 ou Europäische Grundrechte Zeitschrift 1999, 355 (Kosovo), assim como a decisao 2 BvQ 18/03 de 25 de março de 2003 (Iraque)].

As doutrinas correspondentes desenvolvidas nos Estados Unidos, como a "preferred freedoms doctrine" ou a doutrina das "political questions", 12 tiveram êxito na Velha Europa só depois da Segunda Guerra Mundial, mas, por assim dizer, apesar de estarem preparadas para o processo de recepção criativa, só foram bem assumidas com modificaçōes ou então recusadas.

\section{A segunda fase de desenvolvimento}

Esta fase começa depois de 1945, o que não é nenhuma coincidência, porque a recusa dos Estados totalitários ou autoritários na Europa à construção de Estados constitucionais democráticos direcionou a atenção para a possibilidade de uma jurisdição constitucional conformada como de costume.

Realmente, pode-se dizer que, no velho continente, a "hora estelar" da jurisdição constitucional autônoma então começa. Um após o outro, desenvolvem exemplarmente o modelo a Itália (1947) e a República Federal Alemã em sua Lei Fundamental (1949); ${ }^{13}$ foram antes as Constituições dos Länder de Baviera e Essen (1946); inicialmente de forma lenta mas depois mais fortalecida, França na forma do Conseil Constitutionnel da Quinta República (1958), aqui inclusive nos processos de crescimento que "vão recoihendo" competências, autoridade e legitimidade

1 Dentre a literatura sobre a história [da jurisdição constitucional], de uma perspectiva européia: $M$. Cappelletti, Il controllo giudiziario di costituzionalità nel diritto comparato, 1968; P. Cruz Villalón, La formación del sistema europeo de control de constitucionalidad (1919-1939), 1987; J. Luther, Vorstufen europäischer Verfassungsgerichtsbarkeit um 1900. In: M. Kirsch/P. Schiera/A. Kosfeld, Der Verfassungsstaat vor der Herausforderung der Massengesellschaft, 2002, p. 279. Desde uma perspectiva alemã: U. Scheuner, Die Überlieferung der deutschen Staatsgerichtsbarkeit im 19. und 20. Jahrhundert, BVerfG und Grundgesetz, Festgabe aus Anlass des 25-jährigen Bestehens des BVerfG, I, 1976, p. 1 ss; K. Hesse, Stufen der Entwicklung der deutschen Verfassungsgerichtsbarkeit, Jahrbuch des öffentlichen Rechts 46 (1998), p. 1 ss - Grande literatura de Manual: C. Pestalozza, Verfassungsprozessrecht, 3. ed. 1990; E. Benda/E. Klein, Lehrbuch des Verfassungsprozessrechts, 2. ed., 2001. Literatura de comentário destacada: A. Voßkuhle. In: v. Mangoldt/ Klein/Starck, GG III, "art. 93, 94" (2001); AK-Rinken, 2. ed., (1989), vor "art. 93 GG".

12 Sobre a doutrina das "political questions" há a controvérsia entre H. Ehmke e E. Friesenhahn em Veröffentlichung der Vereinigung der Deutschen Staatsrechtslehrer 20 (1963), p. 121 ss (Discusión). Pelo restante: W. Haller, Supreme Court und Politik in den USA, 1972; W. Brugger, Einführung in das öffentliche Recht der USA, 1993, p. 19 ss; M. Piazolo, Verfassungsgerichtsbarkeit und Politische Fragen, 1994. Menciona-se, finalmente, dois "leading cases" sobre a doutrina das "political questions": Pacific States Tel. \& T.CO. v. Oregon, 223 U.S. 118; Baker v. Carr, 369 U.S. 186.

13 Sobre o Tribunal Constitucional Federal alemão como "modelo de uma jurisdiçāo constitucional autônoma", veja minha contribuição do mesmo título em: Festschrift 50 Jahre BVerfG I 2001, p. 311 ss. 
através, por exemplo, do Preâmbulo concebido normativamente e, com isso, o crescimento dos direitos humanos. ${ }^{14}$

Portugal (1976) e Espanha (1978) seguiram com tribunais constitucionais dotados com competências especialmente ricas e começa, tanto no âmbito institucional como também na jurisprudência prática, uma "conversação" intensiva entre os tribunais constitucionais da Europa, naquela época ainda não reunificada. Não pode ficar fora da análise a Suíça, que confia, tanto na velha (1874) como na nova Constituição Federal (2000), ao Tribunal Federal em Lausana a jurisdição constitucional material, muito limitada (art. 289 da nova Constituição Federal). ${ }^{15}$

Devem-se destacar os dois "tribunais constitucionais europeus" em Luxemburgo e Estrasburgo. O Tribunal de Justiça das Comunidades Européias e o Tribunal Europeu de Direitos Humanos, de minha perspectiva, puseram-se em movimento desde o princípio para serem tribunais constitucionais autônomos setorialmente limitados, isto é, no marco do Direito constitucional da Uniāo Européia (antes, Comunidade Econômica Européia) ou no âmbito do Convênio Europeu de Direitos Humanos de 1950. ${ }^{16}$

Nos últimos anos, isto é mais realçado pela intensidade do intercâmbio científico ou pretoriano e pela comparação jurídica dos tribunais constitucionais à escala nacional e européia (fortalecendo-se reciprocamente), por mais que isso nem sempre se diga com suficiente claridade nas sentenças. ${ }^{17}$ Pensa-se simplesmente em princípios como o Estado de Direito, a proporcionalidade, os direitos fundamentais particulares, uma cláusula, escrita ou não, de conteúdo essencial dos direitos fundamentais; ${ }^{18}$ ou as muitas garantias particulares do "due process", que há muito são de natureza europeu-comunitária e formam parte da cultura (jurídica e constitucional) comunitária européia.

\section{A fase de desenvolvimento da jurisdição constitucional desde o "annus mirabilis" de 1989}

Desde 1989, a marcha triunfal da jurisdição constitucional vem ganhando velocidade. ${ }^{19}$ Absolutamente todos os Estados reformados na Europa do Leste

14 Da literatura: K. Oellers-Frahm, Demokratieverständnis und Verfassungsgerichtsbarkeit in der Bundesrepublik Deutschland und in Frankreich, Festschrift Doehring, 1989, p. 691 (699 ss); J. Junker, Die Konstitutionalisierung des Asylrechts durch den französischen Verfassungsrat, 2002, p. 47 ss.

15 Representante da florescente doutrina de Direito político da Suíça: D. Thürer/J.-F. Aubert/J. P. Müller (Hrsg.), Verfassungsrecht der Schweiz, 2001.

16 Sobre o Convênio Europeu de Direitos Humanos: J. A. Frowein/W. Peukert, EMRK-Kommentar, 2. ed., 1996.

17 Da literatura: M. Piazolo (Hrsg.), Verfassungsgerichtsbarkeit, 1995.

18 Da literatura, por exemplo: A. Emmerich-Fritsche, Der Grundsatz der Verhältnismäßigkeit als Direktive und Schranke der EG-Rechtsetzung, 2000; P. Häberle, Die Wesensgehaltgarantie des Art. 19 Abs. 2 Grundgesetz, 3. ed. 1983, p. 266 ss; P. Szezekalla, Die sog. grundrechtlichen Schutzpflichten im deutschen und europäischen Recht, 2002; O. Koch, Der Grundsatz der Verhältnismäßigkeit in der Rechtsprechung des Gerichtshofs der Europäischen Germeinschaften, 2003.

19 Da literatura: A. von Brünneck, Verfassungsgerichtsbarkeit in den westlichen Demokratien, 1991; L. Favoreu, Les cours constitutionnelles, 3. ed. 1996. 
(assim como todos os cinco novos Länder federados alemães) criam uma jurisdição constitucional do tipo autônomo e muitos deles praticam também "refinamentos", como o voto particular (assim, por exemplo, em Kiev ou em Zagreb). Alguns países começam com o domínio dos problemas da transição [assim, especialmente consciente, o Tribunal Constitucional na Hungria, ${ }^{20}$ que conhece inclusive do amparo constitucional popular, e também a Baviera (1946) e a Colômbia (1991/96: artigos 241, 242)].

Em toda a Europa é também reconhecida a rica jurisprudência dos tribunais constitucionais da Polônia, da Croácia e da Eslovênia. A jurisdição constitucional assume na Europa oriental (agora também nos Bálcãs, na Bósnia, com novos textos) ${ }^{21}$ uma função freqüentemente de longo alcance na difícil via ao desenvolvimento do Estado comunista unitário à democracia pluralista. Leva-se adiante não só a "interpretação constitucional", mas também, em uma consideração material, a legislação constitucional pontualmente criativa.

Disso se pode deduzir o dado de que a função da jurisdição constitucional é variável, flexível no tempo e no espaço. Pode se converter em autoridade confirmadora da Constituição segundo a fase de desenvolvimento do concreto Estado constitucional que ela contribui a garantir.

A jurisdição constitucional está incluída como elemento e garantia do "constitucionalismo latino-americano" que se está perfilando. ${ }^{22} \mathrm{Se}$, já em meados do século XIX, o México havia criado pioneiramente o processo do amparo, ${ }^{23}$ hoje pode se alardear de sua Supreme Court tão vital. Em quatro Estados-membros mexicanos há inclusive uma jurisdição constitucional regional própria chamada "Justiça constitucional local". ${ }^{24}$ A jurisdição constitucional autônoma é, em muitos países latino-americanos, um componente integrante da vida constitucional. $\mathrm{O}$ envaidecimento eurocêntrico é, a meu juízo, inadequado. A Colômbia pode des-

20 Sobre isso, J. A. Frowein/T. Marauhn (Ed.). Grundfragen der Verfassungsgerichtsbarkeit in Mittel-und Osteuropa, 1998. Sobre o funcionamento do Tribunal Constitucional húngaro: L. Sóloyom, ibidem, p. 554 ss. (Discusión); G. Brunner, "Grundrechtsschutz durch Verfassungsgerichtsbarkeit in Osteuropa", Festschrift Stern, 1997, p. 1041 ss.

21 Sobre isso, W. Graf Vitzthum (Ed.). Europäischer Föderalismus, 2000. Veja também E. Sarćević, "Verfassunggebung und 'konstitutives Volk': Bosnien-Herzegowina zwischen Natur - und Rechtszustand", Jahrbuch des öffentlichen Rechts 50 (2002), p. 493 ss.

22 Sobre 0 "constitucionalismo latino-americano": P. Häberle, Ein ius commune americanum. In: Íd./M. Kotzur, De la soberania al derecho constitucional común: palabras clave para un diálogo europeo-latinoamericano, 2003, p. 1 ss; H.-R. Horn, Generationen von Grundrechten im kooperativen Verfassungsstaat - Iberoamerikanische Beiträge zum Konstitutionalismus, Jahrbuch des öffentlichen Rechts 51 (2003), p. 663 ss [Nota do Tradutor do Alemão para o Espanhol: uma traduçāo nossa ao espanhol deste último artigo será publicada no Anuario Iberoamericano de Justicia Constitucional, número 8, Centro de Estudios Políticos y Constitucionales, 2004].

23 Sobre isso, E. Ferrer Mac-Gregor, Los tribunales constitucionales en Iberoamérica, 2002; D. G. Belaunde, Latin American Habeas Hábeas, Jahrbuch des öffentlichen Rechts 49 (2001), p. 513 ss; N. Lösing, Die Verfassungsgerichtsbarkeit in Lateinamerika, 2001.

24 E. Ferrer Mac-Gregor, La acción constitucional de amparo en México y España, 2002; E. Ferrer MacGregor/R. Vega Hernández (Coord.), Justicia Constitucional Local, 2003. 
membrar-se com uma guerra civil, mas sua jurisdição constitucional tão intensiva cria textos pretorianos que, pela primeira vez no mundo, logo podem desenvolver força normativa e inclusive se criam "em reserva" (caso se queira, um tanto de utopia, do que, pelas outras coisas, também o Estado constitucional vive). Menciona-se simplesmente o tribunal pan-americano na Costa Rica (para a Convenção Americana de Direitos Humanos). ${ }^{25}$

\section{Primeiras conseqüências teórico-constitucionais}

Apresentemos as primeiras conseqüências: a expansão quase mundial da jurisdição constitucional produz algo mais que simples "materiais" para o marco teórico. Entretanto, não podemos dizer no sentido de Hegel: o racional é real e o real é racional; isso é tão lógico para alguns princípios como "Estado constitucional" (a dignidade humana, por exemplo) - o tipo ideal do Estado constitucional continua bastante "indisposto" e "reincidente", tanto em seu conjunto como em suas particularidades. Mas a jurisdição constitucional pertence desde agora ao programa de contraste ideal e real frente a todo totalitarismo, tanto de direitas como de esquerdas.

A jurisdição constitucional é um garantidor essencial, ainda que não seja o único, frente a todo sistema totalitário ou autoritário. Dito de outra forma, a realidade constitucional viva, também graças à jurisdição constitucional, do Estado constitucional transforma qualquer teoria da jurisdição constitucional em um fator "constitucional" ("razoável").

A olhada até o nível jurídico internacional é natural: os tribunais criados pela ONU nos âmbitos da ex-Iugoslávia e Ruanda, de um lado, e agora, de outro lado, o Tribunal Penal Internacional, não por causalidade batizado em Roma, ${ }^{26}$ constituem pedras de mosaico no caminho até uma "Constituição da Comunidade Internacional”, como a concebeu Verdross já em 1926. ${ }^{27}$ O Tribunal Penal Inter-

25 Sobre isso, veja: Garcia Ramírez (Coord.). La jurisprudencia de la Corte Interamericana de Derechos Humanos, 2001.

26 Texto do Estatuto: A/CONF. 183/9 v. 17-7-1998. Tradução alemã em: Europäische Grundrechte Zeitschrift 1998, p. 618 ss. De la literatura: Ch. Tomuschat, Das Statut von Rom für den internationalen Strafgerichtshof, Friedens-Warte 73 (1998), p. 335 ss; A. Zimmermann, Die Schaffung eines ständigen internationalen Strafgerichtshofs, Zeitschrift für ausländisches öffentliches Recht und Völkerrecht 58 (1998), p. 47 ss; C. Stahn, Zwischen Weltfrieden und materieller Gerechtigkeit: Die Gerichtsbarkeit des Ständigen Internationalen Strafgerichtshofs (IntStGH), Europäische Grundrechte Zeitschrift, 1998, p. 577 ss, 590 ss; U. Fastenrath, Der Internationale Strafgerichtshof, Juristische Schulung, 1999, p. 632 ss; K. Ambos, Der neue Internationale Strafgerichtshof - ein Überblick, Neue Juristische Wochenschrift, 1998, p. 3743 ss, 3746; id., "Verbrechenselemente" sowie Verfahrens-Beweisregeln des Internationalen Strafgerichtshofs, Neue Juristische Wochenschrift, 2001, p. 405 ss. Neste contexto, não se pode deixar de observar também os esforços das Comunidades de responsabilidade, sobretudo na União Européia, para o desenvolvimento de uma administraçao de justiça penal funcional. Cf., por exemplo, G. Dannecker, "Strafrecht in der Europäischen Gemeinschaft", Juristen Zeitung, 1996, p. 809 ss.

27 A. Verdross, Die Einheit des rechtlichen Weltbildes auf Grundlage der Völkerrechtsverfassung, 1923, p. 126 ss; desenvolvido programaticamente em: id., Die Verfassung der Völkerrechtsgemeinschaft, 1926; veja também, finalmente, id./B. Simma, Universelles Völkerrecht, 3. ed., 1984, p. 59 ss. Da abun- 
nacional, ${ }^{28}$ como instituição permanente, pode não só constitucionalizar "peça a peça" o Direito Internacional, mas também pode ter efeito irradiador no interior de cada Estado constitucional-parte: elementos do Direito mundial e do Estado constitucional nacional colaboram daqui até o futuro. ${ }^{29}$

Os juízes exercitados no Direito constitucional nacional inserem nas deliberaçōes de sentença seu instrumental jurídico, tanto metodicamente como quanto ao fundo. O Tribunal Penal Internacional pode ser, de modo indireto, uma peça para a jurisdição constitucional: na medida em que o Direito penal europeu comunitário, também americano comunitário, é indiretamente Direito constitucional (não só nas garantias do due process).

\section{SEGUNDA PARTE: UM MARCO TEÓRICO}

\section{O modelo do Estado constitucional entre o ideal e a realidade: um projeto de desenvolvimento}

O Estado constitucional é o resultado "provisório" de uma longa história de desenvolvimento no espaço e no tempo. Nesse sentido tem-se hoje a consideração como Estado somente aquele que constitui a Constituição: (R. Smend), uma recusa a todas as teorias do Estado do absolutismo tardio, e na Europa de hoje a Constituição do Estado nacional se transformou em uma Constituição parcial no contexto da Constituição européia adolescente.

\footnotetext{
dante doutrina iusinternacional sobre o tema constitucional: A. Ross, The Constitution of the United Nations, 1950; C. W. Jenks, The Common Law of Mankind, 1958, p. 26; H. Mosler, The International Society as a Legal Community, 1980, p. 16; Ch. Tomuschat, Der Verfassungsstaat im Geflecht der internationalen Beziehungen, Veröffentlichung der Vereinigung der Deutschen Staatsrechtslehrer 36 (1978), p. 7 ss; 52 ("Constitución iusinternacional de acompañamiento"); id., Die Bundesrepublik Deutschland und die Menschenrechtspakte der Vereinten Nationen, em: VN 1978, p. 1 ss, 2 (Carta das Naçōes Unidas e Pactos de Direitos Humanos como "núcleo de uma futura Constituiçāo mundial"); L.-C. Chen, An Introduction to Contemporary International Law, 1989, p. 437 ("global constitutive process"); A. Watts, The International Rule of Law, German Yearbook of International Law 36 (1993), p. 15 ss, 22 ("quasiconstitutional framework"); N. Onuf, The Constitution of International Society, EJIL 5 (1994), p. 1 ss, 7 ss, 15 ss (p. 18: Chapter I of the UN-Charta as the "international society's material constitution"); P. Häberle, Verfassungslehre als Kulturwissenschaft, 2. ed., 1998, p. $191 \mathrm{ss}$; B. Fassbender, The United Nations Charter as Constitution of the International Community, Columbia Journal of Transnational Law, 36 (1998), p. 529 ss, 546 e passim; M. Nettesheim, Das kommunitäre Völkerrecht, Juristen Zeitung, 2002, p. 569 ss, 578 ("Derecho comunitario mundial").

28 Sobre o Tribunal Penal Internacional: M. Kotzur, Weltrecht ohne Weltstaat, DÖV 2002, p. 195 ss.

29 Detalhes sobre isso há em P. Häberle, Das "Weltbild" des Verfassungsstaates - eine Textstufenanalyse zur Menschheit als verfassungsstaatlichem Grundwert und "letztem" Geltungsgrund des Völkerrechts, Festschrift M. Kriele, 1997, p. 1277 ss; G. Teubner, Privatregimes = Neo-spontanes Recht und duale Sozialverfassung in der Weltgemeinschaft, Liber amicorum S. Simitis, 2000, p. 437 ss; o "texto clássico" sobre a "comunidade mundial" o proporciona N. Luhmann, Das Recht der Gesellschaft, 1993, p. 551 ss; desenvolvido por R. Stichweh, Zur Theorie der Weltgesellschaft, Soziale Systeme 1 (1995), p. 29 ss; recentemente, M. Kotzur, Weltrechtliche Bezüge in nationalen Verfassungstexten. In: M. Schulte (Hrsg.), Weltrecht, 2003.
} 
O "Estado constitucional europeizado" experimenta tantos contratempos vez ou outra e segue sendo tão propenso ao erro como estando em perigo porque é vivido por homens concretos: é um ganho cultural par excellence no que tem cooperado muitas épocas, naçōes e cidadãos, desde os pensadores clássicos da velha Grécia até os pensadores modernos como Montesquieu, Rousseau, Kant e por último J. Rawls e $\mathrm{H}$. Jonas (O princípio de responsabilidade, 1979, que se transforma em programa constitucional na proteção ambiental), passando pelos maiores juristas, os romanos, que o eram porque trabalhavam pragmaticamente.

Para o Estado constitucional é essencial a dignidade humana como premissa antropológico-cultural e a democracia pluralista como sua conseqüência organizatória em todas suas variantes, até a democracia semidireta na Suíça. O Estado de Direito, a divisão horizontal de poderes, os direitos do homem se somam ao anterior, assim como os chamados direitos políticos ou "liberdades públicas", como os chama a Constituição espanhola (Capítulo II, Seção 1̊n). Outra criação é o federalismo, e seu "irmāo mais novo", o regionalismo, legitimados a partir da idéia da divisão vertical de poder. Exemplos disso são Grã-Bretanha (Escócia, País de Gales), e também se fala agora inclusive em Paris da "França das regiões". Justamente a Itália se caracteriza a esse respeito por um impressionante processo de transformação: a riqueza de imagens das cidades e paisagens culturais da Itália constitui o "humus" ideal para uma res publica que está se convertendo em um federalismo. ${ }^{30}$

A divisão de poderes tem que continuar também no interior dos âmbitos sociais, por exemplo, como divisão social de poder entre os empresários e os trabalhadores ou como divisão publicista entre a imprensa e a radiodifusão e a televisão. A publicidade recebida (materialmente, em atenção à res publica e à salus publica) de Cícero deve ser compreendida pluralmente, o que rege sobretudo para o âmbito dos meios de comunicação. O poder econômico acumulado, o poder da mídia e o poder político põem em perigo o núcleo da sociedade aberta no sentido de Popper.

Nesta imagem global de princípios, instituiçōes, procedimentos corresponde à jurisdição constitucional um lugar destacável. O processo político legitimado democraticamente de forma direta e a jurisdição constitucional legitimada democraticamente de forma indireta estāo em uma relaçāo de diferenciação, de cooperação, mas também de tensão, e isso a serviço da Constituição. Cada juiz constitucional tem, literalmente, que sustentá-los em sua decisão, com freqüência até em seus problemas de consciência. Se o artigo $1^{\circ}$ da Constituiçāo italiana fala em uma "República fundada no trabalho", com isto se alude também certamente a

30 Da literatura: A. D' Atena, L'Italia verso il federalismo, 2002; A. Anzon, La Bundestreue e il sistema federale tedesco: un modello per la riforma del regionalismo in Italia?, 1995; id., I poteri delle Regioni: dopo la Riforma Costituzionale, 2002; T. Groppi, Federalismo e costituzione, 2001. Sobre o regionalismo: J. Woelk, Konfliktregelung und Kompetenzen im italienischen und deutschen Verfassungsrecht, 1999; P. Häberle, Föderalismus, Regionalismus, Kleinstaaten - in Europa. In: G. Zagrebelsky (a cura di), Il federalismo e la democrazia europea, 1994, p. 67 ss. 
seu trabalho como Juiz constitucional. A proposta de fundamentar a República no "mercado" não fez nunca, afortunadamente, texto constitucional.

\section{Os textos clássicos como textos constitucionais no sentido amplo}

Junto aos textos constitucionais de Direito positivo de uma Constituição escrita e as formas de manifestação das não escritas (por exemplo, o Direito judicial), como textos constitucionais em sentido estrito, surgem os textos constitucionais em sentido amplo, como uma parte da cultura. Faz-se referência aos textos clássicos de grandes pensadores, já mencionados. ${ }^{31}$ Eles nos guiam aos juristas, mas também guiam o processo político.

Ainda hoje lemos a Constituição "com os olhos" de Montesquieu ou Kant, e também com os de Popper. A esse respeito, também as palavras dos poetas podem se converter em textos constitucionais em sentido amplo, o que é evidente no caso de F. Schiller ("Sire, dê você liberdade de pensamento": Don Carlos). ${ }^{32}$ Também provocaçōes como a de B. Brecht ("Todo o poder estatal procede do povo, mas aonde vai?") são relevantes, o mesmo que para a Itália o coro de escravos de Nabucco ${ }^{33}$ como "hino nacional secreto" frente a "Padania". Dito brevemente, os textos clássicos desenvolvem força normativa no tempo e no espaço. Em especial para a jurisdição constitucional, dá-se crédito a $H$. Kelsen e, depois de 1945, G. Leibholz, ${ }^{34}$ na forma de seu "informe sobre o status" do Tribunal Constitucional Federal Alemão, ${ }^{35}$ como textos clássicos; na Itália talvez as conferências dos cons-

3! P. Häberle, Klassikertexte im Verfassungsleben, 1981; M. Kotzur, Die Wirkungsweise von Klassikertexten im Völkerrecht, Jahrbuch des öffentlichen Rechts 49 (2001), p. 329 ss.

32 Com isso se alude à obra de teatro, escrita por Schiller em 1787, "Don Carlos", que era uma versāo teatralizada inspirada no Príncipe Carlos, filho primogênito de Felipe II, que padecia de uma enfermidade mental que o fazia ser tremendamente cruel e até sádico e que se viu obrigado a deserdá-lo. Este personagem fascinou poetas e músicos do romantismo europeu. Schiller foi o primeiro que o converteu em um herói romântico e depois Verdi se baseou nesta obra para compor sua impressionante ópera Don Carlo (Nota do Tradutor do Alemão para o Espanhol).

33 Ópera de Verdi, compositor romântico, que presta muita atenção ao exílio do povo hebreu na Babilônia e cuja cena do coro de escravos se converteu no símbolo de protesto político. O coro que interpretam os escravos se converteu logo em um hino do Risorgimento italiano, e em uma sorte do clamor do povo italiano, que se sentiu bastante identificado com os versos deste coro, contra o domínio que os austríacos haviam instaurado na Itália. O título original da obra era Nabucodonosor, mas o povo o batizou em seguida como Nabucco e hoje é conhecido com esse nome (Nota do Tradutor do Alemão para o Espanhol).

34 G. Leibholz, "Der Status des Bundesverfassungsgerichts", Jahrbuch des öffentlichen Rechts 6 (1957), p. 109 ss; H. Kelsen, Wesen und Entwicklung der Staatsgerichtsbarkeit. Outros textos clássicos em: P. Häberle (Ed.), Verfassungsgerichtsbarkeit, 1976. Um texto clássico "recente" é: R. Smend, Festvortrag (1962), Das BVerfG 1951 - 1971, 1971 (também em: P. Häberle (ed.), Verfassungsgerichtsbarkeit, 1976, p. 329 ss).

35 Quando o Tribunal Constitucional Federal alemão começou a funcionar foi colocado sob a autoridade do Ministro Federal de Justiça, enquanto pertencia ao Poder Judicial. Isso provocou uma reação enérgica por parte de diversos juízes constitucionais em defesa de sua autonomia no exercício de sua atividade jurisdicional, e em junho de 1952, após vários meses de discussōes, o tribunal elaborou um duro informe no qual reclamava, em suma, autonomia plena. $O$ informe provocou reações iradas por 
tituintes originários e o Manual de C. Crisafulli. ${ }^{36}$ "Marbury vs. Madison" (1803) é um texto clássico na mão de um juiz, como os Federalist Papers (1787) nāo podem em absoluto ser subestimados para o Estado Constitucional.

\section{Os tribunais constitucionais como participantes reais e fictícios no contrato social}

O paradigma do contrato social, ${ }^{37}$ de J. Locke a J. Rawls, passando por I. Kant, tem hoje que incluir também a jurisdição constitucional. A Constituição é um diário "tolerar e suportar de todos os cidadãos".

Se a "mesa redonda" como gen cultural da humanidade fez história a escala planetária desde a Polônia nos anos 80 , talvez isso tenha sido praticado antes na mesa redonda do Rei Artur, da mesma forma pode ser útil para a jurisdição constitucional o contrato social. Dita jurisdição participa na manutenção, reafirmação e progresso diários do contrato social, comprometida com o desenvolvimento da Constituição como processo público. Suas competências freqüentemente amplas o mostram, assim como sua responsabilidade, pela qual velam conscientemente os juízes e isso não só nas decisōes chamadas centrais mas também nas sentenças básicas. Pelo menos, se pode dizer que a jurisdição constitucional tem participação "pro indiviso" na responsabilidade, no "trabalhar o consenso básico" de um povo. Na sociedade aberta aos constituintes e intérpretes constitucionais lhes corresponde um lugar profissional e especialmente próximo aos cidadãos.

parte do Governo, e particularmente do Ministro de Justiça, e em geral deu lugar a uma fervorosa polêmica na arena política, na qual os social-democráticos e o Bundesrat se alinharam, em termos gerais, com as propostas dos juizes constitucionais, enquanto a colisão governante, e majoritária, no Bundestag, geralmente se opunham. Mas, em todo caso, a luta real se travou entre o Ministro de Justiça e o Tribunal Constitucional, isto é, entre dois velhos companheiros de partido (do Partido Democrático Liberal) que haviam compartido em seu dia uma experiência parlamentar comum: Thomas Dehler, Ministro da Justiça, e o respeitado Presidente do Tribunal, Hermann Höpker Aschoff. O certo é que o prestígio crescente do Tribunal, seu trabalho jurisprudencial - calado, mas decidido e efetivo - e seu rol integrador fizeram que em 1953 o Bundestag pusesse fim à dependência do Tribunal Constitucional do Ministro da Justiça, e em 1960 todas as exigências do informe de 1952 haviam sido já assumidas, apesar de a plena autonomia não se consagrar até 1975, ao se ditar o Regulamento interno do próprio Tribunal, aprovado por seu Pleno. O autor do Informe em questão, tão transcendental, foi o aludido G. Leibholz, cujo projeto não foi sequer discutido antes de sua aprovaçāo. $O$ texto deste informe ("Bericht an das Plenum des Bundesverfassungsgerichts zur 'Status Frage'", de 21 de março de 1952) pode ser consultado no Jahrbuch des öffenlichen Rechts (número 6, 1957, p. 120 ss), Anuário este que foi dirigido por Leibholz e que hoje, por certo, dirige o próprio Häberle. Sobre este episódio, com mais detalhes e bibliografia (em alemão), veja Joaquín Brage Camazano, La acción de inconstitucionalidad, UNAM, México, 2000, p. 37 ss (Nota do Tradutor do Alemão para o Espanhol).

36 Sobre ele: D. Nocilla, Crisafulli - ein Staatsrechtslehrerleben in Italien, Jahrbuch des öffentlichen Rechts 44 (1996), p. 255 ss.

37 Sobre a transposição do paradigma do contrato social ao Tribunal Constitucional Federal alemāo: P. Häberle, Kommentierte Verfassungsrechtsprechung, 1979, p. 425 (438 ss). Sobre isso, também H. SchulzeFielitz, Das BVerfG in der Krise des Zeitgeistes, Archiv des öffentlichen Rechts 122 (1997), p. 1 (14 ss). Outras perspectivas em: G. F. Schuppert/Ch. Bumke (Ed.), Bundesverfassungsgericht und gesellschaftlicher Grundkonsens, 2000. Outra literatura básica: C. Walter, Hüter oder Wandler der Verfassung?, Archiv des öffentlichen Rechts 125 (2000), p. 517 ss; U. Haltern, Integration als Mythos, Jahrbuch des öffentlichen Rechts 45 (1997), p. 31 ss. 
Na ação popular, também na ação coletiva, como na Colômbia, isso salta aos olhos, porém a atividade normal dos juízes constitucionais também poderia proporcionar o paradigma clássico do contrato e uma aquisição de conhecimento: realizado na realidade e construído ficticiamente (no sentido do "como se" de I. Kant). Talvez se elabore em breve um "contrato social europeu": na forma de um referendo na longa e ampla Europa sobre a Constituição da União Européia ${ }^{38}$ (no "contrato entre geraçōes" tem outro campo maior de aplicação).

\section{Tarefas da jurisdição constitucional}

As concretas tarefas de uma jurisdição constitucional resultam da Constituição positiva ou de suas regulaçōes complementares. Mas atrás disso está "o geral": a tarefa de limitação do poder, assim como a Constituição em conjunto também é restriçāo do poder (não só "norma e tarefa", "estímulo e barreira": U. Scheuner e R. Smend); logo, a proteção dos cidadãos, especialmente ali onde há acesso direto ao tribunal constitucional (o recurso de amparo), por isso se diz que tribunal constitucional é um "tribunal cívico" par excellence; outra tarefa é a integração dos órgãos constitucionais, em qualquer controvérsia; ademais a proteção das minorias, que nos Estados federais freqüentemente se alcança através dos conflitcs ou controvérsias federais, corresponde a isso (cf. artigo 93.1, números 2 e 3 da Lei Fundamental de Bonn).

\section{O modelo metódico (aberto): a comparação jurídica como "quinto" método hermenêutico}

F. C. von Savigny canonizou os quatro métodos clássicos de interpretação, também em relação a juristas romanos, como Celso. A meu juízo, há muito tempo se incorporou na prática a comparação jurídica como "quinto" método hermenêutico. ${ }^{39}$ Agora se deve creditá-la também teoricamente como tal sem por isso afirmar uma hierarquia preestabelecida.

O "pluralismo metódico" implica que a interação dos quatro ou cinco métodos interpretativos não é determinável de antemão, nem sequer para os juízes

\footnotetext{
${ }_{38}$ Em 29 de outubro de 2004, os países-membros da Uniāo Européia assinaram o tratado que institui a Constituição da União Européia. Hoje, esta Constituição está sendo ratificada em cada país-membro. Este processo de ratificação não é uniforme, isto é, cada país tem a sua soberania para determinar seu próprio processo de ratificação. Em linhas gerais, pode-se dizer que hả três formas desse processo: a via parlamentar (onde o parlamento do país coloca em votação sua aprovação, ratificando-a), a via do referendo (onde a população, diretamente, vota pela sua aprovaçāo, ratificando-a) e a via mista (onde o parlamento aprova a Constituiçāo e a submete a referendo). Em 2005, este processo de ratificação pelos paises-membros sofreu um duro golpe: França e Holanda rejeitaram o texto dessa Constituiçāo em um referendo popular. Dessa forma. o Conselho Europeu decidiu prorrogar o prazo de $1^{\circ}$ de novembro deste ano para se fazer o levantamento da situação de ratificação da Constituição para meados de 2007, uma vez que verificou a necessidade de se fazer uma maior reflexāo, explicaçāo e debate sobre a Constituição (Nota do Tradutor de Espanhol para Português).

39 Sobre a comparação jurídica como "quinto" método interpretativo: P. Häberle, Grundrechtsgeltung und Grundrechtsinterpretation im Verfassungsstaat, Juristen Zeitung 1989, p. 913 ss.
} 
constitucionais. O peso dos "elementos de interpretaçāo" depende do caso concreto; se controla através de conteúdos últimos e penúltimos de justiça do juiz experimentado (seu juízo), materialmente por princípios constitucionais e também por textos dos clássicos [por exemplo, os textos de Aristóteles até J. Rawls, cfr. BVerfGE 101, 158 (218) = Europäische Grundrechte Zeitschrift 1999, 617 (641)], que operam orientativamente desde o resultado.

Na Europa deve-se levar em consideração, hoje em dia, as correntes de precedentes de outros tribunais constitucionais europeus. A comparação jurídica se refere, no Estado constitucional, à flexível tríade de textos, teorias e doutrinas jurisprudenciais. $\mathrm{O}$ trabalho científico com colaboradores de outros países e culturas jurídicas, como aqui em Roma, pode e deve aprovar muitos trabalhos preliminares. Assim é conhecido que o Tribunal Constitucional de Madri tem recepcionado elementos do federalismo alemão; a carreira do conceito smendiano da "lealdade federal" em toda a Europa, até na Bélgica, é paradigmática. ${ }^{40} \mathrm{O}$ Tribunal Constitucional Federal Alemão pode aduzir um efeito irradiador de sua jurisprudência sobre os direitos fundamentais ao longo da Europa, também de sua jurisprudência do pluralismo no âmbito dos meios de comunicação social ${ }^{41}$ (cfr. também o artigo 20.3 da Constituição espanhola). ${ }^{42}$

\section{Os tribunais constitucionais nacionais como tribunais constitucionais europeus}

A Constituição européia de hoje é uma união de Constituições parciais. Por uma parte, elaborada na Europa em sentido estrito de Roma/Maastricht/Amsterdā/Nice; ${ }^{43}$ por outra, a partir das subsistentes Constituições dos Estados nacionais, que seguem protegidas como parte da "identidade nacional". Na Europa em sentido amplo, isto é, no âmbito da OCDE (atualmente, cinqüenta e cinco membros) e do Conselho da Europa (agora, quarenta e cinco países-membros), se acrescenta o Convênio Europeu de Direitos Humanos, que na Suíça e Áustria rege inclusive com status constitucional, e os textos da OCDE, apesar de que com freqüência estes só constituírem o assim chamado "soft-law".

A Carta de Direitos Fundamentais da Uniāo Européia ${ }^{44}$ poderia, entretanto, desenvolver crescentemente uma força normativa real (na velha Europa da União

\footnotetext{
to A. Alen/P. Peters/W. Pas, "Bundestreue" im belgischen Verfassungsrecht, Jahrbuch des öffentlichen Rechts 42 (1994), p. 439 ss.

41 Desde BVerfGE 12, 205 (259 ss).

42 M. Schellenberg, Pluralismus: $\mathrm{Zu}$ einem medienrechtlichen Leitmotiv in Deutschland, Frankreich und Italien, Archiv des öffentlichen Rechts 119 (1994), p. 427 ss.

43 Aqui o autor se refere aos Tratados que instituiram e formaram a Uniāo Européia, quais sejam, o de Roma, de Maastrich, de Amsterdā e de Nice (Nota do Tradutor do Espanhol para o Português).

44 Sobre a Carta de Direitos Fundamentais da União Européia, agora veja o Kommentar editado por J. Meyer, 2003; veja também G. Zagrebelsky (Ed.), Diritti e Costituzione nell' Unione Europea, 2003.
} 
Européia, é dizer, a dos Quinze e logo os Vinte e Cinco e mais além). ${ }^{45}$ Os dois tribunais constitucionais europeus em Luxemburgo e Estrasburgo ${ }^{46}$ são tais graças a seus textos de referência que vêm a ser Constituições parciais.

Recorde-se também de que cada tribunal constitucional nacional, na aplicação do Direito Constitucional da União Européia e/ou do Direito do Convênio Europeu de Direitos Humanos, é um tribunal comunitário europeu ou um tribunal constitucional europeu. Inclusive o pequeno tribunal do distrito de Bayreuth ou o menor tribunal de Palermo se transforma materialmente neste contexto em um "tribunal constitucional" e isso devido a sua vinculação à lei e ao Direito. O espaço público europeu surge assim também através do espaço público europeu da jurisdição constitucional, diária e constantemente. O espaço público constitucional europeu tem um distinto garantidor em todos os nossos tribunais constitucionais (nos permita aqui por uma vez o pronome possessivo).

\section{Os tribunais constitucionais na flutuação entre o "judicial activism" e o "judicial restraint"}

Aqui pouco se pode prever de uma perspectiva científico-dogmática. Há fases e sentenças particulares nas quais um tribunal constitucional nacional ou europeu intervém amplamente no espaço político (se encontram exemplos tanto nos Estados Unidos ${ }^{47}$ como na Alemanha); há fases nas que um deles, por exemplo, o Tribunal Constitucional alemão, talvez também sob a pressão da ciência, se retrata de algo (por exemplo, a respeito da liberdade de reunião $0^{48}$ ) ou deveria fazê-lo (por exemplo, na relação entre a liberdade de opinião e a proteção da honra).

Muito se deve agradecer aqui ao tato e delicadeza, à sensibilidade política do juiz constitucional, mas também às necessidades do bem comum e aos postulados da justiça (o último, por exemplo, justifica as grandes decisōes fiscais do Tribunal Constitucional Federal Alemão: porque o Parlamento falhou ao longo de décadas) ${ }^{49}$

A jurisdição constitucional não é uma "guardiã da Constituição" per se e não é também alguma coisa como a única guardiã. Em uma democracia pluralista, todos

\footnotetext{
${ }_{45}$ Hoje a Uniāo Européia já conta com os vinte e cinco países-membros e conta com mais cinco países candidatos (Nota do tradutor do Espanhol para o Português).

46 Da literatura: E. G. Mahrenholz, Europäische Verfassungsgerichte, Jahrbuch des öffentlichen Rechts 49 (2001), p. 15 (20 ss).

47 Uma das decisões mais importantes da Supreme Court dos Estados Unidos com um forte realce no judicial activism é United States v. Carolene Products W., 304 U., p. 144, com sua famosa "Footnote 4"; da literatura sobre isso, veja B. Ackermann, Beyond Carolene Products, 98 Harvard Law Review 713 (1985); veja também a discussão monográfica de temas como o judicial activism e o judicial restraint em A. Bickel, The Least Dangerous Branch, 1962.

48 Crítica geral em: R. Scholz, Karlsruhe im Zwielicht - Anmerkungen zu den wachsenden Zweifeln am BverfG, Festschrift Stern, 1997, p. 1201 ss. Uma perspectiva geral recente em: P. Badura, "Verfassung, Staat und Gesellschaft aus der Sicht des BverfG", Festschrift 50 Jahre BverfG II 2001, p. 897 ss.

49 Sobre isso, P. Häberle, Das nationale Steuerverfassungsrecht im Textstufenvergleich, Festschrift Vogel, 2000, p. 139 (151 ss).
} 
os cidadãos são "guardiōes" da Constituição, do cidadão normal até o Presidente do Estado (que, por exemplo, arbitra entre bastidores em uma controvérsia. $\mathrm{O}$ Presidente da República [Staatspresident] Ciampi exigiu com razão há pouco um "respeito recíproco ante a opinião do outro"). Também é guardião o cidadão que impetra um recurso constitucional de amparo, assim como o representante [parlamentar] que defende seu status por meio de uma demanda orgânica (por exemplo, BVerfGE 80, 188 = Europäische Grundrechte Zeitschrift 1989, 288).

A opinião pública científica tem uma responsabilidade especial de seguir criticamente o tribunal constitucional. À opinião pública - na qual, segundo Hegel, como é sabido, jaz "todo o verdadeiro e o falso" simultaneamente - há que prestarlhe menos ouvidos. ${ }^{50}$ Mas conhecemos bem o errado dito, procedente dos Estados Unidos, de que "The Supreme Court follows the elections" - que só pode ser uma máxima caso o entenda de uma maneira totalmente "refinada" (por exemplo, ao final, no "deixar passar" do New Deal na época de Roosevelt). A cultura política dos países que se tomam como exemplo tem importância a esse respeito. 51 "Aceitação" é uma palavra-chave de relevância.

\section{O Direito processual constitucional como "Direito constitucional concretizado"}

Esta máxima, trabalhada em $1976,{ }^{52}$ pretende dizer: um tribunal constitucional deveria viver segundo suas próprias regras de atuação, adaptadas a suas funções especiais, e pode inclusive criá-las à parte.

Quando se busca essas regras de atuação comparativamente em procedimentos judiciais civis ou administrativos ou no código processual penal, isso se dá só porque se quer chegar às experiências, aos conhecimentos, às tradiçōes dos outros tribunais. Mas o totalmente específico de uma Constituição e sua ("penúltima", nunca autêntica) interpretação por um tribunal constitucional deve, entretanto, elaborar-se segundo o procedimento das funçōes do tribunal constitucional. Isso vale para todos os seus procedimentos de julgamento da verdade e da busca da justiça, e também para sua concretização do bem comum. No México, por exemplo, o Direito processual constitucional é uma discussão viva há alguns anos; e também no Peru. ${ }^{53}$

\footnotetext{
so Da literatura: E. Noelle-Neumann, Welche Rolle spielt die öffentliche Meinung für die Entscheidung der Richter?, Festschrift Kriele, 1997, p. 507 ss.

5! Iuscomparativamente, sobre o "judicial self restraint": C. Tomuschat, Das BVerfG im Kreise anderer nationaler Verfassungsgerichte, Festschrift 50 Jahre BverfG I 2001, p. 245 (269 ss). Veja também J. Riecken, Verfassungsgerichtsbarkeit in der Demokratie, 2003, p. 429 ss.

52 P. Häberle, Verfassungsprozessrecht als konkretisiertes Verfassungsrecht, Juristen Zeitung, 1976, p. 377 ss [Nota do Tradutor: Há uma versão em espanhol: Peter Häberle, Nueve ensayos constitucionales y una lección jubilar, apresentação e edição a cargo de Domingo García Belaunde, Palestra/APDC, Lima, 2004, p. 23 ss]. Crítico, E. Klein, Verfahrensgestaltung durch Gesetz und Richterspruch: Das "Prozessrecht des BverfG", Festschrift 50 Jahre BVerfG I 2001, p. 508 (512 ss).
}

53 Sobre isso, D. G. Belaunde, Derecho Procesal Constitucional, 1998; C. Landa, Teoria del Derecho Procesal Constitucional, 2003. 
TERCEIRA PARTE: QUESTŌES PARTICULARES ATUAIS SOBRE A JURISDIÇĀO CONSTITUCIONAL. UMA OBSERVAÇĀO (SELETIVA)

\section{Observação preliminar}

No que se segue, destacam-se algumas questōes particulares de tipo institucional ou jurídico-processual e não materiais, como por exemplo o trabalho pretoriano na existência europeu-comunitária dos direitos humanos (também de seus limites em relação ao terrorismo), a constituição de um "bem comum europeu", a relação das religiōes e Igrejas e o Estado, um tema científico pessoal especialmente de C. Mirabelli (a meu juízo, há hoje um "Direito constitucional europeu da religião" com o Islã como segunda ou terceira religião), ${ }^{54}$ incluindo muitas questões que plantaram a Convenção constitucional da Uniāo Européia, mas que também têm que ser tratadas pelos tribunais constitucionais (por exemplo, a referência a Deus), ou os elementos estruturais de um Direito constitucional pluralista dos meios de comunicação, assim como o status dos partidos e representantes políticos (atualmente no México).

Ter-se-ia que comparar a agenda de muitos tribunais constitucionais para compreender muito rapidamente como muitas questōes jurídico-materiais se plantam paralela ou analogicamente no modelo do Estado constitucional da atual fase de desenvolvimento ou a sua variedade de exemplos, ainda que com todas as diferenças das culturas constitucionais nacionais (exemplos: interrupção da gravidez, liberdade de radiodifusāo).

Este não é agora o tema, mas devem-se discutir algumas questões competenciais, estruturais e processuais dos tribunais constitucionais. O momento processual não pode apenas, como antes em relação ao Estado constitucional, ser subestimado: o desenvolvimento da própria Constituição está inserido em processos (disciplinados), um dos quais é, junto ao processo democrático-parlamentar, o processo ante o tribunal constitucional. Entretanto, inclusive aqui só é possível uma seleção; não se propõe a discussão, por exemplo, do sim ou do não ao chamado "controle normativo abstrato" (artigo 93.1, número 2 da Lei Fundamental).

\section{A eleição dos juízes constitucionais}

A eleição dos juízes constitucionais continua sendo na Alemanha um tema discutido, certamente só de maneira discreta na maior parte das ocasiōes. ${ }^{55}$ Entretanto, a regulação da Lei Fundamental é clara: a eleição tem lugar pelo Bundestag e o Bundesrat por metades, sendo a participação deste último conseqüência do federalismo (artigo 94 da Lei Fundamental).

54 Sobre isso, P. Häberle, Cultura dei Diritti e diritti della Cultura, 2003, p. 247 ss.

55 Da literatura: St. U. Pieper, Verfassungsrichterwahlen, 1998; E. Benda/E. Klein, ibid., p. 54 ss; A. Voßkuhle, ibid., art. 94, números marginais 14 a 16; R. Wahl, Die Reformfragen, Festschrift 50 Jahre BVerfG I, 2001, p. 461 (480 ss). 
A realidade política proporciona razōes para muitas críticas, entretanto, realmente são, em concreto, os partidos políticos os que reclamam para si rigidamente, também publicamente quase sem pudor, as cadeiras de juizes constitucionais, com os quais, devido à maioria de dois terços prescrita pelos $\$ \$ 6^{\circ}$ e $7^{\circ}$ da Lei do Tribunal Constitucional Federal, tudo se negocia antes, no sentido do "do ut dês", no segredo das direções centrais dos partidos.

Entretanto, uma vez eleitos, os juízes do Tribunal Federal se colocam desde o início como independentes e apartidários. Mas no período anterior à eleição devem ao menos "simpatizar" como candidatos com um partido, com freqüência são membros de um partido. O último juiz totalmente "neutro", com a chamada eqüidistância, foi meu mestre científico Konrad Hesse ${ }^{56}$ (há pouco, os "verdes" apresentaram B. O. Bryde como não vinculado a nenhum partido político); na época da fundação do Tribunal Constitucional Federal houve vários assim, como por exemplo G. Leibholz e também E. Friesenhahn.

A Itália é um modelo exemplar exitoso: um terço dos juízes (artigo 135.1 da Constituição italiana) é eleito pelo Presidente do Estado, que desde logo no conjunto é mais forte que o Presidente Federal alemão (a eleição pelos tribunais supremos ordinários e administrativos é igualmente exemplar; menciona-se aqui o atual Presidente R. Chieppa). Como se sabe, até agora cada presidente italiano do Estado teve uma mão muito boa para eleger a esse terço de magistrados e, assim, o modelo italiano foi assumido como modelo também por alguns Estados em vias de reforma da Europa do Leste (assim, o artigo 140.3 da Constituição da Romênia de 1991, artigo 147.1 da Constituição da Bulgária de 1991).

A Itália, por sua parte, poderia certamente, seja dito com todo o respeito, aprender de outros países: as regiōes deveriam participar, a meu juízo, na eleição dos juízes em certa medida, como corresponde a um novo regionalismo ou inclusive federalismo "à italiana" (A. D'Atena) (com uma segunda Câmara das Regiōes), e também para isso há modelos de Direito comparado (atualmente, o modelo do federalismo ${ }^{57}$ opera também para o Iraque).

Por fim, a má práxis dos partidos políticos na Alemanha se passou ao Tribunal das Comunidades Européias. Pelo menos em duas ocasiōes um juiz de grandes méritos enviado da Alemanha a Luxemburgo não viu prorrogado seu mandato devido a discussões políticas entre a União Cristã Democrática (CDU) e o Partido Social Democrático (SPD) (de uma maneira totalmente distinta ocorre, por exemplo, na Espanha).

Minha proposta apresentada já em Bonn em 1971 de intercalar hearings públicas dos candidatos antes da eleição dos juízes (assim, agora, o artigo 112.2, frase $4^{\underline{a}}$ da Constituição de Brandenburgo de 1992) é uma práxis que há nos Estados

56 Ilustrativamente: T. Oppermann, Das Bundesverfassungsgericht und die Staatsrechtslehre, Festschrift 50 Jahre BVerfG I, 2001, p. 421 ss.

57 Sobre o Senado como "Câmara das Regiōes?", veja Mattarella, Das Zweikammersystem in Italien, Archiv des öffentlichen Rechts 108 (1983), p. 370 (388 ss). 
Unidos ante o Senado e traz também, certamente, perigos. Esta proposta foi aceita até agora político-juridicamente só pelo Partido dos "Verdes", indubitavelmente sem êxito.

\section{O voto particular como "jurisprudência alternativa"}

O voto particular ${ }^{58}$ é, da minha perspectiva, o referendo da concepção da "Constituição como processo público" (1969/1978). Procedente dos Estados Unidos, praticado sob a vigência da Lei Fundamental de Bonn desde 1970, a possibilidade do voto particular dos juízes constitucionais decora atualmente várias Constituiçōes, sendo especialmente impressionante o artigo 164.1 , frase $1^{\underline{a}} \mathrm{da}$ Constituição espanhola (1978), ${ }^{59}$ e também os Estados reformados da Europa do Leste a conhecem, assim como o Convênio Europeu de Direitos Humanos de Estrasburgo.

A práxis ou a realidade e a teoria falam a favor do voto particular, até então só utilizado com medida. Nos Estados Unidos, os votos particulares desenvolveram no tempo uma força normativa reconhecida, com freqüência a médio ou longo prazo, da mesma forma que ocorreu na Alemanha. A minoria de hoje será a maioria de amanhã (em geral, um ingrediente da democracia). Um exemplo especial de tal "mudança repentina" é o voto particular da Magistrada Senhora Rupp von Brünneck em matéria de proteção pelo direito de propriedade de posições de Direito público [E 32, 129 (142), e E 40, 65 (83 ss)].

Do ponto de vista da Teoria da Constituição, o voto particular confirma o processo de desenvolvimento em que está toda Constituição: o voto particular é - junto com a revisão total, a revisão parcial, a mutação constitucional e a reforma legislativa - uma peça de mosaico na imagem global do "tempo e Constituição". O voto particular pode, como "jurisprudência alternativa", "anular" outras propostas judiciais de solução, pode operar pacificadoramente, porque a parte derrotada se considera que foi levada a sério e que pode chegar a longo prazo a uma "conversação jurídica" aberta em matéria constitucional.

Há que se presumir que a possibilidade e a realidade dos votos particulares, que no Tribunal Constitucional Federal alemāo têm uma tradição própria faz tempo (através de juízes individuais que freqüentemente votaram separadamente, como W. Geiger e H. Simon), contribuem para que a opiniāo majoritária dos juízes se manifeste de maneira mais conseqüente, mais lógica, mais direta; não precisa

58 Sobre os votos particulares, basicamente: K. Schlaich, Das Bundesverfassungsgericht, 4. ed., 1997, p. 38 ss; P. Häberle, Kommentierte Verfassungsrechtsprechung, 1979, p. 24 ss; R. J. Schweizer/P. Sutter, Das Institut der abweichenden oder zustimmenden Richtermeinung im System der EMRK, Festschrift Trechsel, 2003, p. 107 ss. Da literatura, ademais: G. Roellecke, Sondervoten, Festschrift 50 Jahre BVerfG I 2001, p. 363 ss - Literatura "originária": W. Geiger, Abweichende Meinungen, 1989.

59 A redação desta parte do citado artigo é: "As sentenças do Tribunal Constitucional publicam-se no boletim oficial do Estado com os votos particulares, se houver" (Nota do Tradutor do Espanhol para o Português). 
nenhum "compromisso" "forçado" no seio do Tribunal. A linha de argumentação de uma decisão poderia ser mais convincente na medida em que o juiz cujo critério não se impōe possa publicar seu voto dissidente.

Muitos presidentes da Corte Costituzionale italiana me perguntaram uma vez ou outra em particular nas minhas visitas a Roma há treze anos pelo voto particular (alemão): os Presidentes Casavola, Corasaniti, A. Baldassarre, há pouco também já L. Elia, G. Zagrebelsky, o atual vice-presidente (no ano de seu grande "Diritto mite": 1992). Pronunciei-me sempre, certamente com prudência acadêmica, a favor de uma introdução deste instrumento quase ideal da jurisdição constitucional.

Os Estados constitucionais consolidados com jurisdição constitucional poderosa como a Itália podem verdadeiramente "se permitir" o voto particular, caso não esteja consagrado autonomamente [na Constituição: esclarecimento do Tradutor do Alemão para o Espanhol], pelo menos por lei. $O$ voto particular eleva a legitimidade do "voto da maioria" a ele vinculado dialeticamente, assim como a da jurisdição constitucional e inclusive do Estado constitucional em seu conjunto. $O$ fato de a Espanha, como jovem democracia desde o começo, em 1978, ter-se aventurado a dotar de voto particular a seu Tribunal Constitucional, é algo que pertence ao "milagre" deste Estado constitucional, assim como à "transiçāo" (depois de Franco).

\section{0 recurso constitucional de amparo 60}

Como último exemplo, deve-se mencionar o recurso constitucional de amparo. ${ }^{61} \mathrm{Na}$ Alemanha, este recurso transforma o Tribunal Constitucional Federal em "Tribunal cidadão" par excellence (cfr. artigo 93.1, número 4a da Lei Fundamental). Em nossa cultura política já não há que discutir mais sobre este recurso. Pela via do recurso constitucional de amparo se assenta jurisprudência importante. Ainda que, devido à sobrecarga do Tribunal Constitucional Federal através desta modalidade processual, se reclama cada vez mais uma reforma e se aconselha alguma coisa como o procedimento livre de admissão, como na Supreme Court dos Estados Unidos, entretanto, conserva-se até hoje, a meu juízo por boas razões, o reconhecido processo do recurso constitucional de amparo.

\footnotetext{
60 O recurso constitucional de amparo tem a terminologia na Alemanha de Verfassungsbeschwerde, que é traduzida como recurso constitucional. Em linhas gerais, pode-se dizer que o recurso constitucional de amparo é o procedimento através do qual o cidadāo tem acesso à Corte Suprema de seu país, após esgotar todas as instâncias judiciais. Neste ponto, ele se assemelha ao recurso extraordinário brasileiro. Porém, o recurso extraordinário brasileiro tem uma aplicação mais ampla, por permitir que seja impetrado o recurso contra qualquer decisão que viole a Constituição Federal. Nos outros países, esse âmbito de aplicação é mais reduzido, por referir-se somente à violação de direitos e liberdades fundamentais (Nota do tradutor de Espanhol para Português).

${ }^{61}$ Sobre isso, P. Häberle, Die Verfassungsbeschwerde im System der bundesdeutschen Verfassungsgerichtsbarkeit, Jahrbuch des öffentlichen Rechts 45 (1997), p. 89 ss (aparecido como livro na Itália: 2000). Veja também G. Brunner, Der Zugang des Einzelnen zur Verfassungsgerichtsbarkeit im europäischen Raum, Jahrbuch des öffentlichen Rechts 50 (2002), p. 191 ss; sobre o "Tribunal cidadão", P. Häberle, Jahrbuch des öffentlichen Rechts, ob. cit., 45 (1997), p. 89 ss - Da literatura recente: C. Gusy, Die Verfassungsbeschwerde, Festschrift 50 Jahre BVerfG I 2001, p. 641 ss.
} 
Outros países, como Espanha (artigo 161.1, número 6), na Europa do Leste: por exemplo, Polônia (artigo 188, número 5, da Constituição de 1997) e Eslovênia (artigo 160 da Constituição de 1991), na América Latina: por exemplo Colômbia e México, conhecem igualmente este instrumento com outro nome (amparo), de grande êxito na práxis. Certamente, há outros procedimentos à disposiçāo do cidadão: na Escandinávia procede o Ombudsmann, defendido com afinco muito cedo no México (por H. Fix Zamudio) e que teve êxito também na Polônia; entretanto, o (subsidiário) recurso constitucional de amparo me parece, no sistema da proteção jurídica pelo Tribunal Constitucional, um elemento ótimo. Não está a Itália há muito tempo em condiçōes para ele?

\section{QUARTA PARTE: PERSPECTIVA E CONCLUSÃO}

Esta conferência procede de um "estrangeiro": que, como tal, está obrigado, naturalmente, à prudência ("academical self restraint"), especialmente quando se trata de questōes complicadas da jurisdição constitucional na Itália.

Por isso, não permiti posicionar-me sobre a questão discutida entre vocês de se a Corte poderia guardar um "minuto de paz" na sessão pública. Seja como for, a discussão sobre o tema "Estado constitucional e paz" se intensificou. Não se trata só do artigo 11 da Constituição italiana, mas sim muito mais em geral da questão de se o dever da paz do Estado constitucional da atual fase de desenvolvimento é imanente; a "paz" escrita [cfr. também o artigo 26 da Lei Fundamental, Preâmbulo da Polônia; o artigo 6.1 da Constituição da Hungria (1990/1997) contém a cláusula de paz absolutamente mais ampla, junto com o artigo 9 da Constituição do Japão; cf. também o artigo 63.2 da Constituição da Eslovênia (1992) e o artigo 135.2 da Constituição da Lituânia (1992) ] ${ }^{62}$ ou não escrita não é um conceito "por si". Só pode se contemplar em relações intensas com a justiça, a verdade e a liberdade (assim, com afinco o Papa João Paulo II nestes dias). Poder-se-ia pensar na figura jurídica dos "princípios gerais do Direito", que incluem as normas relevantes do Direito internacional, sobretudo da ONU em matéria do Conselho de Seguridade, no interior de cada Estado constitucional.

Uma determinada atuação de um órgão constitucional como a Corte em Roma poderia aqui ter operado criando consciência. Por outro lado, está certamente o mandato de prudência judicial. Mudamos aqui ou na questão do Iraque, como não, os limites de toda jurisdição constitucional; também a ciência é dolorosamente consciente. A guerra do Iraque esgotou a todos nós, literalmente, tanto interior como cientificamente.

Entretanto, o otimismo científico continua sendo precisamente hoje irrenunciável, também pela responsabilidade frente aos "juristas europeus" das próximas

${ }_{62}$ Sobre o tema "Paz e Constituição", o título do mesmo nome: E. Benda, Archiv des öffentlichen Rechts 109 (1984), p. 1 ss. Da literatura de comentário ao art. 26 da Lei Fundamental: I. Pernice. In: H. Dreier, GG-Kommentar, 2 1998; R. Streinz. In: Sachs, Grundgesetz, 3. ed. 2002, art. 26; U. Fink. In: v. Mangoldt/Klein/Starck, GG II, 2000, art. 26. 
geraçōes. A história constitucional, também a da jurisdição constitucional, não é um Selbstläufer ${ }^{63}$ no sentido de um caminho de progresso despejado; há também passos para trás, decisões erradas, como entre nós os alemães, por exemplo, a "sentença anticrucifixo" (BVerfGE 93, 1 = Europäische Grundrechte Zeitschrift 1995, 359), cuja problemática vocês, por meio de seu Presidente C. Ruperto, solucionaram genialmente à italiana, ao tempo que, com consciência cultural, recolocaram uma obra de arte com uma representação da Virgem Maria. ${ }^{64}$

Apesar de todos os limites, continuam sendo grandes, ${ }^{65}$ dignas de admiração!, as possibilidades da jurisdição constitucional, nos Estados Unidos como na Europa. Seu Tribunal já explorou muitas possibilidades, se eu o vejo corretamente, sem "custos" desproporcionais. Se isso pode dizê-lo um alemão, não me sinto mais como um "estrangeiro" na "Europa de Schengen", ${ }^{66}$ ao mais tardar, todos nós somos "cidadãos europeus". A teoria dos três elementos do clássico G. Jellinek deve ser reelaborada radicalmente. ${ }^{67}$

A unidade européia não relativiza só o território estatal assim como o chamado poder estatal, não só integra os povos europeus, também converte a cultura (plural) no primeiro e último "elemento do Estado", melhor: no verdadeiro fundamento da Constituição. Permita-me o dito majestoso: como alemão se é hoje na Itália nacional, a Itália é "terra amiga", não o "estrangeiro". ${ }^{68}$

O que nós os juristas temos que elaborar arduamente e de maneira reduzida outros o anteciparam de maneira grande. Goethe, graças à cultura, a sua cultura, foi, na Itália, durante sua viagem, italiano, e até sua morte e além dela, um "nacio-

\footnotetext{
63 A palavra Selbstläufer é difícil de traduzir neste contexto. Faz referência a algo (aqui, a jurisdição constitucional) que tem o êxito pretendido por si mesma, sem ter que se esforçar muito para conseguilo (Nota do Tradutor do Alemão para o Espanhol).

64 Com isso se faz referência, conforme me esclarece o professor Pegoraro, a que recentemente, na ocasião de certas reformas, se substituiu na Sala de Audiências da Corte Costituzionale o crucifixo que ali estava localizado tradicionalmente por um quadro da Virgem Maria, obra de arte e não símbolo religioso (Nota do Tradutor do Alemāo para o Espanhol).

65 Veja também G. Zagrebelsky. In: C. M. Martini/G. Zagrebelsky (Ed.), La domanda di giustizia, 2003, p. 3 ss.

${ }_{66}$ O acordo de Schengen significa a eliminação do controle de fronteiras pelos países-membros da União Européia e também a participaçāo no acervo. Todos os países-membros participam do acervo, porém, nem todos eliminaram o controle de fronteiras. Dos quinze primeiros países-membros da União Européia, Reino Unido e Irlanda pcssuem o controle de suas fronteiras. Os dez países membros que se incorporaram este ano ainda terāo o controle de suas fronteiras eliminados pelo Conselho da Uniāo Européia. Fazem parte ainda do acordo Schengen Islândia, Noruega e Suiça, sendo que esta última faz parte somente do acervo (Nota do Tradutor de Espanhol para Português).

67 Sobre esta revisāo da doutrina dos três elementos: P. Häberle, Verfassungslehre als Kulturwissenschaft, 2. ed. 1998, p. 620 ss. Em relação à Europa, id., Europäische Verfassungslehre, 2001/2002, p. 348 ss.

68 Utiliza o autor aqui um jogo de palavras dificilmente traduzivel, porque emprega a palavra "Inländer" (que traduzimos aqui por "nacional") em contraposiçāo a "Ausländer" (estrangeiro), e logo designa a Itália como "terra amiga" ("Freundesland") em contraposição à terra estrangeira ("Ausland"), engenhoso jogo léxico que não é possível traduzir ao espanhol (Nota do Tradutor do Alemão para o Espanhol).
} 
nal", como nenhum outro, fora de Frederico II, ${ }^{69}$ o outro "personagem ilustrado" na relaçāo ítalo-germânica. Fisicamente, Goethe teve que superar muitos passos fronteiriços, já no lago de Garda muito dolorosos, mas espiritual e mentalmente não foi assim. Até hoje, a comunidade científica italiana olha com especial intensidade até Weimar, talvez inclusive mais intensamente que nós, os próprios alemães, em honra a Goethe e à Constituição de Weimar. Nós olhamos agradecidos à Itália, à Itália que hoje luta por uma via do regionalismo pioneiramente criado em 1947 a um federalismo próprio.

Posto que hoje todo juiz constitucional nacional, como todo juiz nacional, ao mesmo tempo é um juiz constitucional europeu e juiz comunitário, na medida em que aplica o Convênio Europeu de Direitos Humanos ou o Direito da União Européia, já não há "passos de fronteira" por onde quer que seja, sobretudo em matéria de jurisdição constitucional da fase atual de desenvolvimento.

69 Faz-se referência a Frederico II, Imperador da Alemanha e Rei da Sicília (1194-1250) (Nota do Tradutor do Alemão para o Espanhol). 